\title{
NEW OPPORTUNITIES FOR LEARNING FOREIGN LANGUAGES IN UZBEKISTAN
}

\author{
Dilorom Babajanova
}

Professor, Doctor of Historical Sciences, Uzbek State University of World Languages, Uzbekistan

\section{ABSTRACT}

The article analyzes the introduction of teaching foreign languages in Uzbekistan, the processes associated with new opportunities for teaching languages, as well as the problems of training specialists in foreign languages on the basis of archival data and government decisions.

KEYWORDS: - Foreign language training, new opportunities, government, foreign language, school, institute, specialist, teacher, education, program, local staff.

\section{INTRODUCTION}

In today's process of globalization, the effect of the radical reform of the education system of Uzbekistan is evident in all areas related to this area. The state pays special attention to the teaching and further development of foreign languages in the education system, which is a key sector of socio-economic, political and cultural life of the country, one of the vital factors that directly affect the morale of the population. at the policy level. At a video conference chaired by the President of the Republic of Uzbekistan Sh. Mirziyoyev on May 6, 2021 on measures to improve the system of teaching foreign languages, the problems in the system were analyzed in detail and priorities were identified. On this basis, the issue of attitudes to foreign language teaching is addressed in the Resolution of the President of the Republic of Uzbekistan dated May 19, 2021 No PP-5117 "On measures to bring the promotion of foreign languages in the Republic of Uzbekistan to a qualitatively new level": "... education in foreign languages It is no coincidence that the need to develop as a policy priority, radically improve the quality of education in this area, attract qualified teachers to the field and increase the population's interest in learning foreign languages "[1].

\section{THE MAIN FINDINGS AND RESULTS}

Today, there is a so-called independent Uzbekistan in the world, which has its own high potential and unique prestige, and a high-spirited nation with a rich culture lives in this country. Emphasizing that the role, prestige and position of this nation in the world community are changing radically, President of the Republic of Uzbekistan Shavkat Mirziyoyev said: we will mobilize all the forces and capabilities of our state and society "[2.146]. Therefore, in the above-mentioned video conference, the real situation in some parts of the country does not correspond to the planned grand plans, in particular, the vacancy of more than 2,000 foreign language teachers in the education 
CURRENT RESEARCH JOURNAL OF HISTORY 2(6): 43-48, June 2021

DOI: https://doi.org/10.37547/history-crjh-02-06-10

ISSN 2767-472X

(C)2021 Master Journals

\section{Crossref dof 80 Google}

Accepted 21 th June, 2021 \& Published 26 th June, 2021

system, the absolute unsatisfactory quality of foreign language teaching in 1,400 schools. it was noted that only $4 \%$ of teachers had a national and international language certificate, and $49 \%$ did not pass the test [3].

This is a sad situation, of course. Uzbekistan's policy of openness, active entry into the world market, expanding international cooperation in all areas increase the need for knowledge of foreign languages. Today, 25 higher education institutions in the country teach in foreign languages. In 2016, there were only 7 of them. The number of graduates who have received an international language certificate has increased 10 times in the last 3 years [4].

In recent years, as a result of diplomatic relations with foreign countries, there has been a growing need for personnel with a deep understanding of foreign languages, a correct understanding of the socio-economic situation, political processes and international relations. As a result of changing attitudes to the study and teaching of foreign languages, the issue of training, educating a harmoniously developed generation, continuous teaching of foreign languages in the demonstration of their talents in science has risen to the top. Pedagogical institutes have been established in many cities of the country, and with the opening of foreign language faculties, there have been positive developments in the training of foreign language specialists.

In the process of globalization, a foreign language specialist is required to have a thorough knowledge of one of the foreign languages, regardless of the field in which he / she works, and the legal basis for success is reflected in laws, decrees and programs. The Uzbek State University of World Languages, which is the main institution of higher education, is responsible for the implementation of these documents and the training of specialists fluent in foreign languages. At the same time, many educational institutions are equipped with language equipment and modern pedagogical technologies.

As a result of the measures taken, the Uzbek State University of World Languages published 63 textbooks in the field of foreign language education and specialties in 2009-2012. In order to introduce modern information technologies in the educational process, teaching technologies have been developed and applied to the educational process by specialists in each subject. The Uzbek State University of World Languages was preparing bachelors in international journalism, translation theory and practice, English, Russian, French, German, Spanish and Chinese. The increase in the number of foreign languages taught at the university over the past years was an indication of the growing need for specialists in various foreign languages in the country [5.3].

Based on the current situation, in order to prevent such problems, a center for teaching foreign languages and preparing applicants for higher education has been opened at the Samarkand State Institute of Foreign Languages. Each year, more than 2,000 entrants study foreign languages at these centers. Based on the President's instructions, it is planned to increase the number of foreign language learners in the centers to 5,000 each year. These centers are staffed by foreign teachers in collaboration with the British Council, the US Embassy, the Goethe Institute, the Alliance Française, KOICA, the Confucius Institute and the DAAD.

In 2021 alone, 350 students were awarded scholarships to study at prestigious foreign universities through the El-Yurt Umidi Foundation. This is 5 times more than in previous years. However, the situation on the ground is not in line with the intended grand plans. In particular, more than 2,000 foreign language teachers remain in the education 
CURRENT RESEARCH JOURNAL OF HISTORY 2(6): 43-48, June 2021

DOI: https://doi.org/10.37547/history-crjh-02-06-10

ISSN 2767-472X

(C)2021 Master Journals

\section{Crossref do) 81 Google}

Accepted 21 th June, 2021 \& Published 26 th June, 2021

system. The quality of foreign language teaching in 1,400 schools is absolutely unsatisfactory. Only $4 \%$ of teachers in this system have national and international language certifications. There are no such certified teachers in Khanabad and Quvasoy, Zafarabad, Mirishkor, Turtkul, Sherabad and Uzun districts. Issues such as 49 percent of foreign language teachers in schools failing the test were analyzed in detail at the meeting, and priorities were identified. "It is time to establish a new system of foreign language teaching in our country, which will be a solid foundation for the future. Since we have set ourselves the goal of building a competitive state, from now on school, high school, college and university graduates must be fluent in at least 2 foreign languages. This strict requirement should become the main criterion of the activity of the head of each educational institution, - said the President [6].

The above resolution emphasizes the task of popularizing the study of foreign languages among the population and creating the necessary conditions for their perfect mastering, coordinating the introduction of internationally recognized programs and textbooks for teaching foreign languages at all levels of education and developing modern teaching skills. Undoubtedly, as the President said in the video conference, the Uzbek State University of World Languages and Oriental Studies, along with the Samarkand State Institute of Foreign Languages, one university in each region has been designated as a base for foreign languages. Through the basic educational institution established in each region, new opportunities will open for foreign language teachers in all districts of the region, even in remote villages, to increase their qualification and methodological capacity, enrich their knowledge, skills and abilities, to teach foreign languages to schoolchildren. It was noted that this will increase the quality of foreign language teaching. For example, the Samarkand State
Institute of Foreign Languages has established a complex scientific-methodical center for advanced training and retraining in foreign languages for all levels of education. It is planned to train 1,304 people, a total of 2,704 foreign language teachers and educators from the system [7].

It is no coincidence that the President said, "It is time to establish a new system of foreign language teaching, which will be a solid foundation for the future." As stated in the Address to the Oliy Majlis on December 29, 2020, "following the acute requirements, priority should be given to the study of physics and foreign languages next year" [8] and on May 6, 2021 in a video conference on improving foreign language teaching. and by analyzing the results obtained, it is important to conduct research aimed at overcoming the problem of "the real situation on the ground in foreign language teaching is unsatisfactory" [9].

In Uzbekistan, the issue of training competitive personnel who have mastered foreign languages, modern science, radically change the educational process, update the quality of education on the basis of international experience has risen to the level of state policy. In this regard, the President said that "we are all proud that our young people are rightly able to take responsibility for the future of our country, becoming a decisive force for today and tomorrow [10.145].

Today, the most important condition for the development of the intellectual potential of the youth of independent Uzbekistan is the acquisition of broad knowledge and professional skills, as well as active communication with peers abroad, comprehensive awareness of all events, innovations and changes in the world. Great importance is attached to the in-depth study of foreign languages.

Recently, the interest in learning foreign languages is growing. The fact that the future of 
CURRENT RESEARCH JOURNAL OF HISTORY 2(6): 43-48, June 2021

DOI: https://doi.org/10.37547/history-crjh-02-06-10

ISSN 2767-472X

(C)2021 Master Journals

\section{Crossref do) 81 Google}

Accepted 21 th June, 2021 \& Published 26 th June, 2021

the country in the construction of a democratic civil society depends on knowledgeable, wise and spiritually mature personnel increases the importance of improving the education system in line with modern requirements in the implementation of the tasks set out in the regulations. It is very important that the young people of the Republic of Uzbekistan, who are modern specialists and confidently enter the world community, have a perfect knowledge of foreign languages and be able to communicate freely in them. Therefore, as noted at the meeting chaired by the President on the mass study of foreign languages, from now on graduates of schools, lyceums, colleges and universities will be required to be fluent in at least 2 foreign languages.

The 21st century has been called the "age of multilingualism" by the European Union, and the problem of effective learning and teaching of foreign languages is becoming increasingly important. In particular, raising the intellectual potential of young people in Uzbekistan, gaining a wide range of knowledge and professional skills, as well as active communication with peers abroad, keeping abreast of all events, innovations and changes in the world today, is the most important condition for acquiring great intellectual wealth. great opportunities have been created for them to study foreign languages in depth.

Like many other countries in the world, Uzbekistan pays special attention to the teaching and learning of foreign languages as a social direction of the state. there is every opportunity to keep abreast of the news.

In order to overcome the existing shortcomings in the teaching of foreign languages, many decisions have been made, measures have been developed and practical work has been done to train foreign language teachers, to improve the teaching of foreign languages to students. In particular, the Uzbek State University of World Languages, as a base institution of higher education, which has made a significant historical contribution to the further improvement and improvement of foreign language teaching, solves the problem of shortage of foreign language teachers throughout the country, especially in rural areas. , led the work on problem solving such as the creation of training and methodological manuals. In this regard, the state, as the main reformer, has fulfilled a number of important tasks. In particular, the National Training Program has been developed, areas and specialties that are important for the future of our country have been identified, and the tasks of higher education in the training of quality personnel have been identified. However, a number of shortcomings in the next stage, including the fact that the knowledge, skills and competencies to be acquired by graduates in each specialty are not clearly developed by basic universities, which, first of all, do not always take into account modern requirements and employer's needs. It should be noted that the plan is an obstacle to the training of quality personnel, such as the excess of general humanities and the inability to study in-depth specialties, increasing the number of classes and less attention to independent education [11]. Each higher education institution in the country has close cooperation with the world's leading scientific and educational institutions, the widespread introduction of advanced pedagogical technologies, curricula and teaching materials based on international educational standards in the educational process, teaching activities, master classes, qualifications. Active involvement of highly qualified teachers and scientists from foreign partner educational institutions in training courses, on the basis of which on a systematic basis to organize internships, retraining and advanced training of masters, young teachers and researchers of 
CURRENT RESEARCH JOURNAL OF HISTORY 2(6): 43-48, June 2021

DOI: https://doi.org/10.37547/history-crjh-02-06-10

ISSN 2767-472X

(C)2021 Master Journals

\section{Crossref dof 80 Google}

Accepted 21 th June, 2021 \& Published 26 th June, 2021

higher educational institutions of the republic. A

"Road Map" has been developed.

So far, a wide range of opportunities have been created for young people to develop in all areas, to acquire modern knowledge and skills, foreign languages, to be healthy and well-rounded in all respects, to find a worthy place in life, especially to know foreign languages. It was a great historical event that in 1992, as one of the fruits of independence in our country, the Uzbek State University of World Languages was established and rebuilt on the basis of a special decision. In particular, young people are proud of the fact that more than $80 \%$ of girls are educated in the school, which was originally taught in 4 languages and today, more than 20 foreign languages. Here students get acquainted not only with the language of other nations, but also with their history, culture, spirituality, customs.

Actions on five priority areas of development of the Republic of Uzbekistan in 2017-2021: to determine the future of the country, to educate the younger generation to be physically healthy, intellectually developed, independent-minded, strong-willed, loyal to the Fatherland, deepen democratic reforms and develop civil society identified as important tasks in the strategy [12]. The document also pays special attention to the development of education and science, support of state youth policy, in-depth study of foreign languages and integrated learning of languages into sciences.

The meeting also paid special attention to the training of specialists in the higher education system, noting that today the level of foreign language proficiency of $78 \%$ of professors and teachers in universities is unsatisfactory. It was also noted that starting from the new academic year, the number of admission quotas for foreign languages will be doubled to 16,000, and the state grant will be tripled "[13]. In this regard, all higher education institutions in the country are setting their own plans and have begun preparations for the admission of the 2021/2022 academic year. In particular, construction of educational buildings and complete overhaul of existing ones, creation of new literature and textbooks, construction of modern information and resource centers, as well as student housing with all conditions for students to live in modern buildings, investment in modern information technology including.

One of the most discussed topics these days was the quality of foreign language teaching, which was raised by the President during a video conference. Introduce bonuses for teachers with international language certificates to improve the situation in this area; introduction of the requirement for new (or re-hired) teachers to have a national and international language certificate; reimbursement of a portion of tuition costs for teachers with high scores; allocation of funds for each district and city in order to improve the quality of foreign language teaching; opening of specialized schools with the involvement of foreign teachers; measures have been announced to introduce a presidential award to encourage schools that achieve the best results in foreign language proficiency.

It was also said that every school graduate should have perfect knowledge of two foreign languages. It was noted that it is necessary to introduce textbooks and methodologies that meet international standards, as well as to teach special subjects in foreign languages in universities. At the same time, they spoke about the introduction of a foreign language as a mandatory requirement for employment and appointment to new positions in government agencies, as well as the introduction of additional bonuses for employees who have a deep knowledge of a foreign language. It was announced the establishment of the Agency for the Promotion of Foreign Language Learning under the Cabinet of Ministers. 
CURRENT RESEARCH JOURNAL OF HISTORY 2(6): 43-48, June 2021

DOI: https://doi.org/10.37547/history-crjh-02-06-10

ISSN 2767-472X

(C)2021 Master Journals

\section{Crossref do) 81 Google}

Accepted 21 th June, 2021 \& Published 26 th June, 2021

Many of the announced measures are reflected in the Presidential Decree "On measures to bring the promotion of foreign language learning to a qualitatively new level." However, attempts to improve the quality of foreign language teaching were made some time ago - on the basis of a large-scale presidential decree of December 10, 2012 "On measures to further improve the system of learning foreign languages." Despite "excellent" reports and reports in the press at the time that "this decision is being successfully implemented," the president's press service said that "the situation on the ground does not correspond to the planned grand plans."

\section{Conclusion}

In short, the current focus on science, investment in education will be programmed to help the younger generation to become self-sacrificing professionals for the future development of our country. After all, knowledge of a foreign language penetrates into the inner world of the nation, which, in turn, plays an important role in enriching the thinking of a spiritual person and increasing the intellectual potential of a harmoniously developed generation.

\section{ReFERENCES}

1. Resolution of the President of the Republic of Uzbekistan No. PP-5117 of May 19, 2021 // HTTPS://LEX.UZ/DOCS/5426736

2. Shavkat Mirziyoev. We will resolutely continue our path of national development and raise it to a new level. Volume 1 Tashkent: "Uzbekistan" NMIU, 2017. P.145-146.

3. I. Tukhtasinov. Teaching foreign languages opens the door to new opportunities //https://yuz.uz/news/chet-tillarnioqitish-yangi-imkoniyatlar-eshiginiochadi--
4. https://president.uz/uz/lists/view/4327

5. Ismailov A., Boqieva G. Our university in the years of independence // Philological issues. Scientific-methodical journal. Tashkent, 2011, № 3. - B.3.

6. Resolution of the President of the Republic of Uzbekistan No. PP-5117 of May 19, 2021 // // HTTPS://LEX.UZ/DOCS/5426736

7. https://review.uz/oz/post/poslanieprezidenta-uzbekistana-shavkatamirziyoyeva-oliy-majlisu

8. https://www.youtube.com/channel/UC62 RfVrE7-JfA8JFBM03WUA

9. Do'stov J. Problems caused by new trends in the system of foreign language teaching / Competence-based approach to management-oriented foreign language learning./https://dba.uz/wpcontent/uploads/2019/07/04-07-19.8280.pdf

10. https://www.youtube.com/channel/UC62 RfVrE7-JfA8JFBM03WUA

11. Decree of the President of the Republic of Uzbekistan Shavkat Mirziyoyev PF-4947 "On the Action Strategy for further development of the Republic of Uzbekistan". February 7, 2017. Collection of Legislation of the Republic of Uzbekistan, Tashkent. 2017, №6, Article 70.

12. Foreign languages: where is the road to the destination//https://www.gazeta.uz/uz/2 021/05/21/foreign-languages/ 